\title{
KANDUNGAN LOGAM BERAT MERKURI PADA IKAN TUNA (YELLOWFIN DAN BIGEYE) DAN TUNA-LIKE(SWORDFISH) HASIL TANGKAPAN DARI SAMUDERA HINDIA DAN SAMUDERA PASIFIK
}

\section{Study on Mercury Concentrations in Tuna (Yellowfin and Bigeye) and Tuna-like (swordfish) Caught from Indian and Pacific Oceans}

\author{
Tri Handayani ${ }^{1 *}$, Mohamad Syamsul Maarif ${ }^{2}$, Etty Riani ${ }^{3}$, dan Nazori Djazuli ${ }^{4}$ \\ ${ }^{1}$ Program Studi IImu Pengelolaan Sumberdaya Alam dan Lingkungan, Sekolah Pascasarjana Institut Pertanian Bogor, Bogor, Indonesia \\ ${ }^{2}$ Sekolah Bisnis, Institut Pertanian Bogor, Bogor, Indonesia \\ ${ }^{3}$ Departemen Manajemen Sumberdaya Perairan, Fakultas Perikanan dan Ilmu Kelautan, Institut Pertanian Bogor, Bogor, Indonesia \\ ${ }^{4}$ PT. Dharma Samudera Fishing Industries, Tbk., Jakarta, Indonesia \\ *Korespondensi Penulis: yen.han27@gmail.com
}

Diterima: 13 Desember 2018; Direvisi: 20 Maret 2019; Disetujui: 17 Mei 2019

\begin{abstract}
ABSTRAK
Komoditi tuna dan tuna-like merupakan hasil perikanan yang memiliki nilai ekonomis bagi Indonesia. Namun, logam berat dapat terakumulasi di biota ini karena posisinya sebagai top predator. Penelitian ini menganalisis 895 data sekunder hasil pengujian merkuri yellowfin tuna (Thunnus albacares), bigeye tuna (Thunnus obesus) dan swordfish (Xiphias gladius), yang merupakan data official control oleh Badan Karantina, Pengendalian Mutu dan Keamanan Hasil Perikanan (BKIPM). Tujuan penelitian adalah untuk menganalisis kandungan merkuri yellowfin tuna, bigeye tuna dan swordfish, serta korelasinya dengan berat ikan dan menganalisis data kontaminan merkuri yellowfin tuna, bigeye tuna dan swordfish terkait pencemaran habitat perairan asal bahan baku di Samudera Hindia dan Samudera Pasifik. Metode analisis menggunakan regresi linier dan analisis t-test. Pengujian merkuri menggunakan Atomic Absorption Spectrophotometric (AAS). Hasil analisis menunjukkan bahwa kandungan merkuri sangat bervariasi antar jenis, berat dan asal perairan. Dua jenis tuna dari kedua perairan mengandung merkuri $<1,0 \mathrm{mg} / \mathrm{kg}$, kandungan merkuri yellowfin tuna berkisar antara 0,06 $\pm 0,06 \mathrm{mg} / \mathrm{kg}$ hingga $0,33 \pm 0,18 \mathrm{mg} / \mathrm{kg}$, sedangkan bigeye tuna antara $0,05 \pm 0,02 \mathrm{mg} / \mathrm{kg}$ hingga $0,33 \pm 0,14 \mathrm{mg} / \mathrm{kg}$. Berat kedua ikan tidak berkorelasi terhadap kandungan merkuri, namun pada bigeye tuna terdapat perbedaan konsentrasi merkuri yang signifikan antara kelompok berat 1-10 kg/ekor dengan ukuran yang lebih besar (>100 kg/ekor). Sebaliknya pada swordfish, kandungan merkuri meningkat

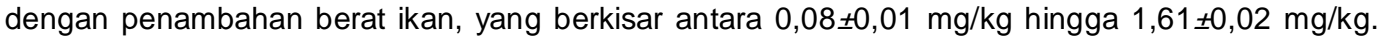
Terdapat $34 \%$ (>50 kg) swordfish dari Samudera Hindia yang kandungan merkuri nya melebihi batas $1,0 \mathrm{mg} / \mathrm{kg}$. Kandungan merkuri tuna dan tuna-like hasil tangkapan di Samudera Hindia lebih tinggi dibandingkan Samudera Pasifik dan berbeda nyata, sehingga dapat mengindikasikan Samudera Hindia lebih tercemar merkuri.
\end{abstract}

KATA KUNCI : merkuri, Samudera Hindia, Samudera Pasifik, tuna dan tuna-like

\section{ABSTRACT}

Tuna and tuna-like species are considered as highly economic fish species for Indonesia. However, as a high-tropic level predatory species, tuna may accumulate heavy metal contaminants. This study analyzed 895 secondary data of mercury levels in tuna and tuna-like species, based on official control conducted by Badan Karantina Ikan, Pengendalian Mutu dan Keamanan Hasil Perikanan (BKIPM). The objectives of this study were to analyze correlations between mercury contents in yellowfin, bigeye and swordfish with fish weight and fish habitats (Indian and Pacific Oceans). Mercury was analyzed using Atomic Absorption Spectrophotometric (AAS). The data was analyzed based on linear regression and t-test. The result found that mercury concentrations varied significantly among species, weight and fish habitats. Two tuna species from two habitats, have mercury concentration of $<1.0 \mathrm{mg} / \mathrm{kg}$. Mercury in yellowfin ranged from $0.06 \pm 0.06 \mathrm{mg} / \mathrm{kg}$ to $0.33 \pm 0.18 \mathrm{mg} / \mathrm{kg}$, while in bigeye it ranged from $0.05 \pm 0.02 \mathrm{mg} / \mathrm{kg}$ to $0.33 \pm 0.14 \mathrm{mg} / \mathrm{kg}$. For yellowfin and bigeye, mercury concentrations were weakly associated with fish weight, except in bigeye, there was a significant difference of mercury concentration between the fish at the group of 1-10 kg with the larger size (>100 kg). In contrast, a strong relationship between mercury content with fish 
weight was observed in swordfish, where mercury concentration increased with increasing fish weight. It ranged from $0.08 \pm 0.01 \mathrm{mg} / \mathrm{kg}$ to $1.60 \pm 0.02 \mathrm{mg} / \mathrm{kg}$, and $34 \%$ of swordfish caught from the Indian Ocean (>50 kg of weight) have mercury content that exceeded $1.0 \mathrm{mg} / \mathrm{kg}$. Mercury concentration of tuna and tuna-like caught from the Indian Ocean were significantly higher than those caught from the Pacific Ocean, which could indicate that the Indian Ocean was more polluted interm of mercury than the Pacific Ocean.

KEYWORDS: Indian Ocean, mercury, Pacific Ocean, tuna and tuna-like

\section{PENDAHULUAN}

Tuna dan tuna-like merupakan sumber pangan yang mengandung protein sangat penting untuk kesehatan, rendah kolesterol dan tinggi kandungan asam lemak omega-3 (n-3) (Llaurado et al., 2016). Jenis ikan ini memiliki nilai ekonomis penting, menyumbang ekonomi global lebih dari 40 milyar USD per tahun, dengan produksi hampir mencapai 5 juta ton (Galand, Rogers \& Nickson, 2016). Ekspor tuna dan tuna-like Indonesia tahun 2014 sebesar 203.444 ton dengan nilai mencapai 677.900 USD (KKP, 2017). Di lain pihak, ikan dapat terkontaminasi oleh metil merkuri, yaitu bentuk merkuri yang sangat beracun dan mempunyai dampak buruk pada kesehatan, salah satunya perkembangan syaraf anak-anak (Llop et al., 2017).

Merkuri $(\mathrm{Hg})$ adalah logam berat yang sangat berbahaya bagi kesehatan manusia, yang dapat merusak atau menurunkan fungsi sistem syaraf pusat, merusak komposisi darah, paru-paru, ginjal dan organ vital lainnya, apabila terkonsumsi melebihi ambang batas (Darmono, 1995), merusak organ tubuh (Riani, 2015) dan dapat mengakibatkan cacat bawaan pada embrio yang dilahirkan (Riani, Sudarso \& Cordova, 2014). Keberadaan merkuri di perairan dapat terjadi secara alamiah, melalui proses pelapukan dari bebatuan dan debu yang mengandung logam dari aktivitas gunung berapi, pelapukan tebing dan tanah serta aerosol dan partikulat dari permukaan lautan (Connell \& Miller, 1995). Penggunaan merkuri pada industri, mencapai \pm 3.000 jenis, antara lain pada industri pengolahan bahan-bahan kimia, insektisida untuk pertanian, obat-obatan, dan pertambangan (Alfian, 2006). Diperkirakan sekitar 350.000 ton merkuri tersimpan di lautan di seluruh dunia (Sunderland \& Mason, 2007), dua pertiga dari jumlah tersebut berasal dari aktifitas manusia dari berbagai jenis industri (Lamborg et al., 2014). Di perairan, proses dekomposisi oleh bakteri dapat mengubah merkuri menjadi senyawa organik metil merkuri, selanjutnya diserap oleh jasad renik dan masuk dalam rantai makanan, yang kemudian akan terjadi akumulasi dalam tubuh hewan air seperti ikan dan kerang.

Sistem peringatan dini terhadap kasus pangan dan pakan Uni Eropa, yaitu Rapid Alert System for Food and Feed (EU-RASFF) melaporkan adanya penolakan produk tuna dan tuna-like karena kandungan merkuri yang melebihi standar 1,0 ppm. Pada tahun 20142017 berturut-turut terjadi 99, 85, 98 dan 133 kasus penolakan, antara lain dari di Italia, Belanda, Spanyol, Portugal, Jerman dan beberapa negara lainnya (EC, 2017). Total kasus penolakan produk tuna dan tunalike dari Indonesia pada tahun 2014-2017 sebanyak 13 kasus, berasal dari unit pengolahan ikan yang mengambil bahan baku dari tangkapan di Samudera Hindia. Beberapa penelitian menunjukkan bahwa kandungan kadar merkuri pada ikan bervariasi berdasarkan asal perairan, negara dan berat ikan yang berbeda (Burger \& Gochtel, 2004; Kantun, Malawa \& Rapi, 2014).

Sumber tangkapan tuna Indonesia, berasal dari selatan Samudera Hindia dan Samudera Pasifik, yang umumnya diproses di unit pengolahan ikan di DKI Jakarta, Bali dan Sulawesi Utara. Volume ekspor tuna dari kedua wilayah tersebut mencapai 131.823 ton dan 196.335 ton untuk tahun 2016 dan 2017, dengan nilai masing-masing sebesar 686,7 juta USD dan $1.042,1$ juta USD (BKIPM, 2018a).

Mengingat cukup banyak kasus penolakan produk tuna dan tuna-like karena kandungan merkuri yang melebihi standar di pasar internasional dan Indonesia merupakan salah satu negara penghasil tuna dan tuna-like di dunia, sedangkan penelitian tentang kandungan merkuri pada tuna dan tuna-like masih kurang, maka studi ini penting untuk dilakukan. Tujuan penelitian adalah untuk mengetahui tingkat cemaran merkuri pada ikan tuna dan tuna-like, mengetahui korelasi antara berat ikan dan kandungan merkuri pada masing-masing jenis ikan tuna dan tuna-like serta membandingkan tingkat cemaran pada ikan tuna dan tuna-like hasil tangkapan dari selatan Samudera Hindia dan barat Samudera Pasifik.

\section{BAHAN DAN METODE}

\section{Bahan}

Bahan yang digunakan pada penelitian ini yaitu data sekunder hasil pengujian merkuri yellowfin tuna (Thunnus albacares), bigeye tuna (Thunnus obesus) dan swordfish (Xiphias gladius), yang merupakan hasil 
monitoring dalam rangka official controlyang dilakukan BKIPM pada tahun 2012-2017 terhadap unit pengolahan ikan yang mengekspor komoditi tuna dan tuna-like dalam bentuk utuh, loin, saku atau steak ke negara-negara dengan persyaratan tinggi (Uni Eropa dan Amerika). Data yang dikumpulkan sebanyak 895, terdiri dari 443 data dari tujuh unit pengolahan ikan di Muara Baru-Jakarta dan BenoaBali untuk hasil tangkapan dari Samudera Hindia, dengan jumlah data sebanyak 167, 126 dan 150 masing-masing untuk jenis yellowfin, bigeye dan swordfish, serta 452 data yang berasal dari lima unit pengolahan ikan yang berlokasi di Bitung-Sulawesi Utara untuk hasil tangkapan dari Samudera Pasifik, masing-masing yaitu yellowfin, bigeye dan swordfish sebanyak 179, 218 dan 55 data. Monitoring merkuri dilakukan secara rutin sebagai persyaratan penerapan hazard analysis critical control point (HACCP) di unit pengolahan ikan dan penerbitan sertifikat kesehatan/ health certificate $(\mathrm{HC})$ untuk ekspor. Penentuan kandungan merkuri dilakukan di laboratorium yang bersertifikat ISO 17025 dengan metode SNI 01-2354.62006 (BSN, 2006), menggunakan alat atomic absorption spectrophotometer (AAS) furnace dari Perkin Elmer AAnalyst 800, dan dengan metode pengabuan basah.

\section{Metode}

Berat ikan dikelompokkan berdasarkan klasifikasi berat komersial yang digunakan dalam perdagangan internasional, yaitu: $1-10 \mathrm{~kg}, 11-30 \mathrm{~kg}, 31-50 \mathrm{~kg}, 51$ -
$100 \mathrm{~kg}$ dan $>100 \mathrm{~kg}$. Data monitoring merkuri masingmasing jenis ikan ditabulasi berdasarkan klasifikasi berat ikan, kemudian dilakukan analisis korelasi antara rata-rata kandungan merkuri dengan berat ikan berdasarkan area penangkapan menggunakan regresi linier. Analisis $t$-test digunakan untuk membandingkan tingkat pencemaran di Samudera Hindia dan Samudera Pasifik.

\section{HASIL DAN PEMBAHASAN}

\section{Kontaminan Merkuri pada Ikan Tuna dan Tuna-like}

Dari rata-rata total kandungan merkuri yellowfin tuna sebanyak 346 data, tidak ditemukan data yang lebih tinggi dari $1,0 \mathrm{mg} / \mathrm{kg}$, yang merupakan batas aman yang dipersyaratkan secara nasional dan internasional (BSN, 2009; CAC, 2015; EC, 2008). Rata-rata total kandungan merkuri yellowfin tuna bervariasi mulai yang terendah sebesar $0,160 \pm 0,061$ $\mathrm{mg} / \mathrm{kg}$, yaitu yellowfin tuna hasil tangkapan di Samudera Pasifik pada kelompok berat ikan 11-30 $\mathrm{kg} / \mathrm{ekor}$, hingga yang tertinggi sebesar $0,331 \pm 0,182$ $\mathrm{mg} / \mathrm{kg}$ dari ikan hasil tangkapan di Samudera Hindia dengan kelompok berat ikan 51-100 kg/ekor, seperti pada Gambar 1.

Hasil analisis terhadap 344 data hasil monitoring kandungan merkuri pada bigeye tuna menunjukkan bahwa rata-rata total kandungan merkuri masih berada di bawah ambang batas $1,0 \mathrm{mg} / \mathrm{kg}$. Rata-rata kandungan

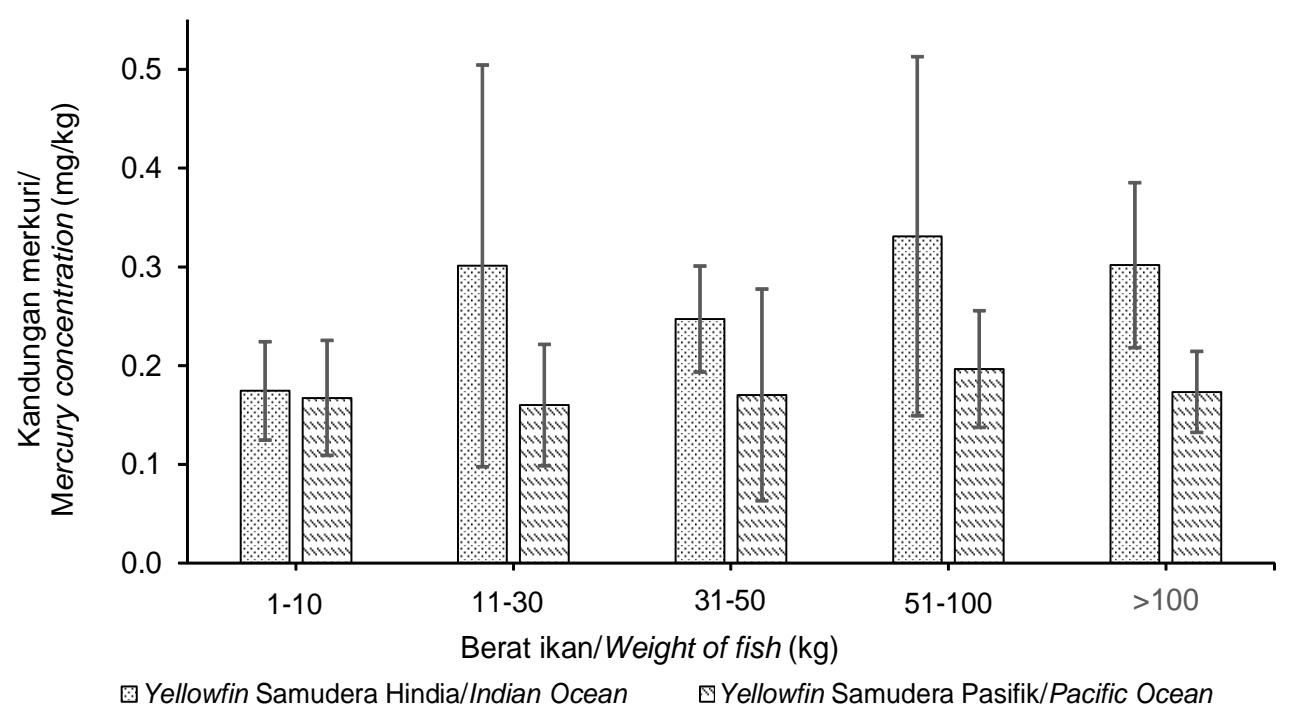

Sumber: BKIPM (2018b)

Gambar 1. Kandungan merkuri yellowfin tuna (Thunnus albacares) hasil tangkapan di Samudera Hindia dan Samudera Pasifik

Figure 1. Mercury concentrations in yellowfin tuna (Thunnus albacares) caught from the Indian and the Pacific Oceans 


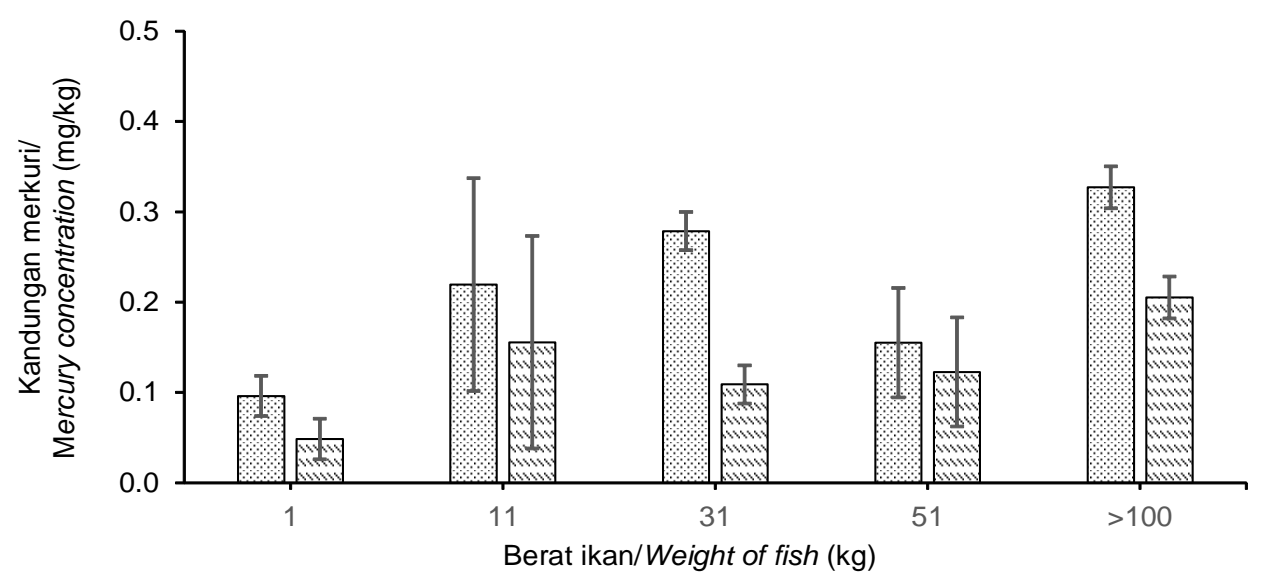

@ Bigeye tuna Samudera Hindia/Indian Ocean $₫$ Bigeye tuna Samudera Pasifik/Pacific Ocean

Sumber: BKIPM (2018b)

Gambar 2. Kandungan merkuri bigeye tuna (Thunnus obesus) hasil tangkapan dari Samudera Hindia dan Samudera Pasifik

Figure 2. Mercury concentrations in bigeye tuna (Thunnus obesus) caught from the Indian and the Pacific Oceans

merkuri bervariasi berdasarkan berat ikan, dengan nilai terendah sebesar $0,05 \pm 0,02 \mathrm{mg} / \mathrm{kg}$ yang berasal dari hasil tangkapan di Samudera Pasifik pada kelompok berat ikan $1-10 \mathrm{~kg} / \mathrm{ekor}$, dan nilai tertinggi sebesar $0,33 \pm 0,14 \mathrm{mg} / \mathrm{kg}$ dari ikan hasil tangkapan di Samudera Hindia dengan kelompok berat ikan $>100 \mathrm{~kg} / \mathrm{ekor}$, sebagaimana terlihat pada Gambar 2.

Rata-rata total kandungan merkuri swordfish dari 205 sampel terlihat bahwa konsentrasi merkuri terendah sebesar $0,08 \pm 0,01 \mathrm{mg} / \mathrm{kg}$ dan tertinggi
$1,61 \pm 0,02 \mathrm{mg} / \mathrm{kg}$. Kandungan merkuri hasil tangkapan di Samudera Pasifik berkisar antara 0,08-0,57 mg/ $\mathrm{kg}$, dan tidak ada yang lebih dari $1,0 \mathrm{mg} / \mathrm{kg}$, sedangkan swordfish hasil tangkapan dari Samudera Hindia sebanyak 27,3\% yang melebihi batas aman $1,0 \mathrm{mg} / \mathrm{kg}$, seperti terlihat pada Gambar 3 .

Dari hasil analisis diketahui bahwa rata-rata kandungan merkuri pada yellowfin dan bigeye tuna berfluktuasi dan tidak melebihi ambang batas $1,0 \mathrm{mg} /$ $\mathrm{kg}$, yang merupakan batas maksimal merkuri yang

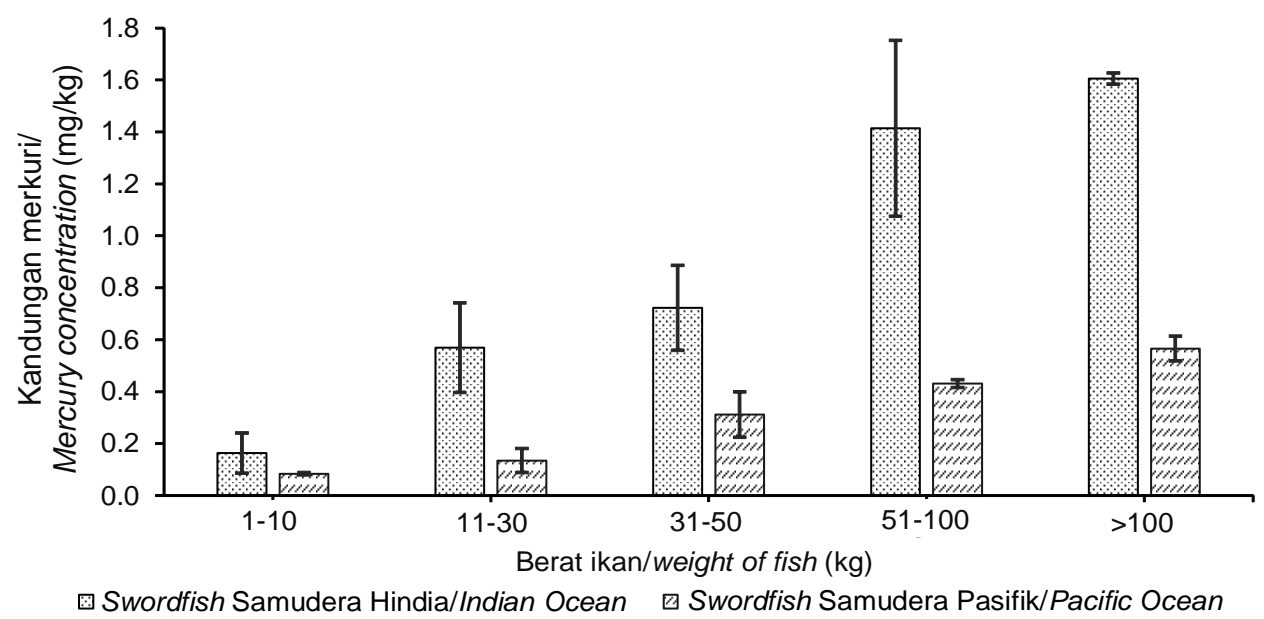

Sumber: BKIPM (2018b)

Gambar 3. Kandungan merkuri swordfish (Xiphias gladius) hasil tangkapan dari Samudera Hindia dan Samudera Pasifik

Figure 3. Mercury concentrations in swordfish (Xiphias gladius) caught from the Indian and the Pacific Oceans 
ditetapkan oleh banyak negara (BSN, 2009; CAC, 2015; EC, 2008). Hal ini sesuai dengan studi yang dilakukan oleh Jinadasa, Jayasinghe, Edirisinghe, \& Wickramasinghe (2015) di perairan Samudera Hindia, bahwa rata-rata kandungan merkuri dari semua klasifikasi berat yellowfin tuna dan bigeye tuna tidak ditemukan melebihi 1,0 mg/kg. Kandungan merkuri yang lebih rendah dari $1,0 \mathrm{mg} / \mathrm{kg}$ juga ditemukan pada yellowfin tuna dari hasil tangkapan di Selat Mozambik, yaitu $0,7 \mathrm{mg} / \mathrm{kg}$ dari hasil tangkapan di Kepulauan Reunion (Kojadinovic, Potier, Corre, Cosson \& Bustamante, 2006), dan yellowfin tuna di perairan Samudera Pasifik dan Atlantik masing-masing berkisar antara $0,12-0,56 \mathrm{mg} / \mathrm{kg}$ dan 0,03-0,82 $\mu \mathrm{g} / \mathrm{kg}$ (Kojadinovic et al., 2006)

Beberapa penelitian menunjukkan bahwa merkuri terakumulasi pada rantai makanan pada ikan yang bersifat predator, seperti cucut, swordfish dan marlin, sehingga kadar merkuri pada ikan tersebut lebih tinggi dibandingkan dengan jenis ikan lainnya (Jinadasa, Edirisinghe, \& Wickramasinghe, 2013; Nicklisch, Bonito, Sandin, \& Hamdoun, 2017). Ikan predator seperti swordfish, tuna dan hiu yang berada pada tingkat trofik atas pada rantai makanan akan terpapar kadar metil $\mathrm{Hg}$ yang lebih tinggi dari mangsanya (Chen, Chen, Chang \& Huang, 2007; Yilmaz, 2009). Konsentrasi merkuri pada yellowfin dan bigeye tuna cenderung lebih rendah jika dibandingkan dengan swordfish, diduga dipengaruhi oleh perbedaan jenis mangsa, laju pertumbuhan, tingkat kerakusan dan tingkat trofik pada rantai makanan (Ghaeni, Pour, \& Hosseini, 2015; Kojadinovic et al., 2006; Yi, Tang, Yi, Yang, \& Zhang, 2017). Yi et al. (2017) menyatakan bahwa perbedaan kandungan merkuri antara tuna dan tuna-like disebabkan perbedaan fisiologis spesies, tingkat kerakusan (feeding habits), tingkat pertumbuhan, rentang hidup, pola migrasi dan posisi rantai makanan. Storelli, Giacominelli-Stuffler, Storelli, \& Marcotrigiano (2005) menyatakan bahwa swordfish merupakan jenis predator puncak yang memiliki aktifitas metabolisme intensif, sehingga diperlukan suplai energi dan tingkat kerakusan yang tinggi, yang berakibat pada tingginya akumulasi polutan. Sebagai top predator yang menempati tingkat trofik yang lebih tinggi, swordfish menjadi tempat terakhir terjadinya bioakumulasi dan biomagnifikasi "trace element' pada rantai makanan (Gobert et al., 2017).

Hasil analisis regresi linier terhadap data rata-rata kandungan merkuri pada yellowfin tuna terlihat bahwa rata-rata konsentrasi merkuri ikan tuna cenderung tidak berkorelasi dengan berat ikan. Nilai $R$ square $\left(R^{2}\right)$ masing-masing sebesar 0,0839 untuk yellowfin tuna hasil tangkapan dari Samudera Hindia dan 0,0155 untuk hasil tangkapan dari Samudera Pasifik, seperti pada Gambar 4. Rata-rata kandungan merkuri bigeye tuna juga cenderung tidak berkorelasi dengan berat ikan, terlihat dari nilai $\mathrm{R}^{2}$ sebesar 0,1111 untuk hasil tangkapan dari Samudera Hindia dan 0,1951 untuk

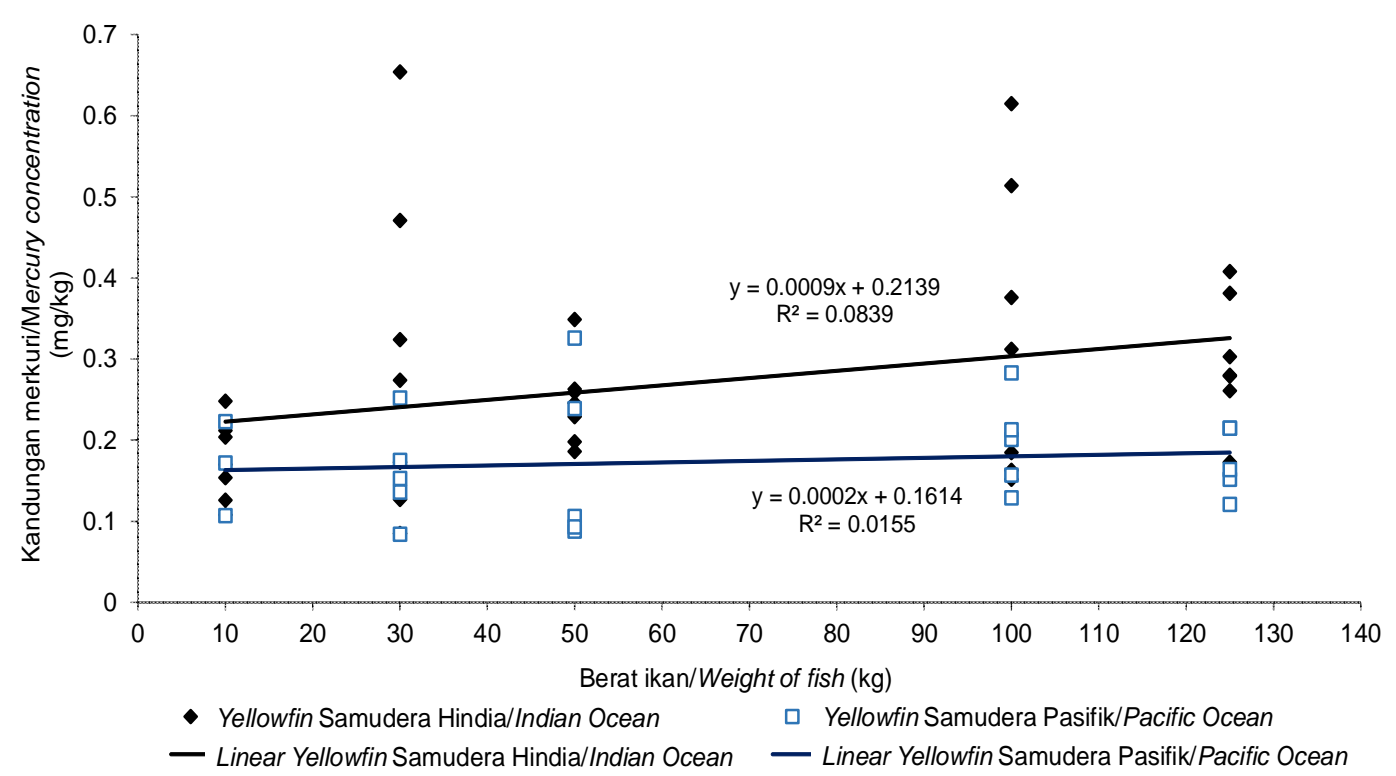

Sumber: BKIPM (2018b)

Gambar 4. Korelasi antara konsentrasi merkuri dengan berat yellowfin tuna hasil tangkapan di Samudera Hindia dan Samudera Pasifik

Figure 4. Correlation between mercury concentration and weight of yellowfin tuna caught from the Indian and the Pacific Oceans 
hasil tangkapan dari Samudera Pasifik (Gambar 5). Hasil analisis terhadap kandungan merkuri pada swordfish menunjukkan, konsentrasi merkuri berkorelasi kuat dengan berat ikan, terlihat dari nilai
$R^{2}$ yaitu masing-masing sebesar 0,8572 untuk hasil tangkapan dari Samudera Hindia dan 0,8456 untuk hasil tangkapan dari Samudera Pasifik, seperti pada Gambar 6.

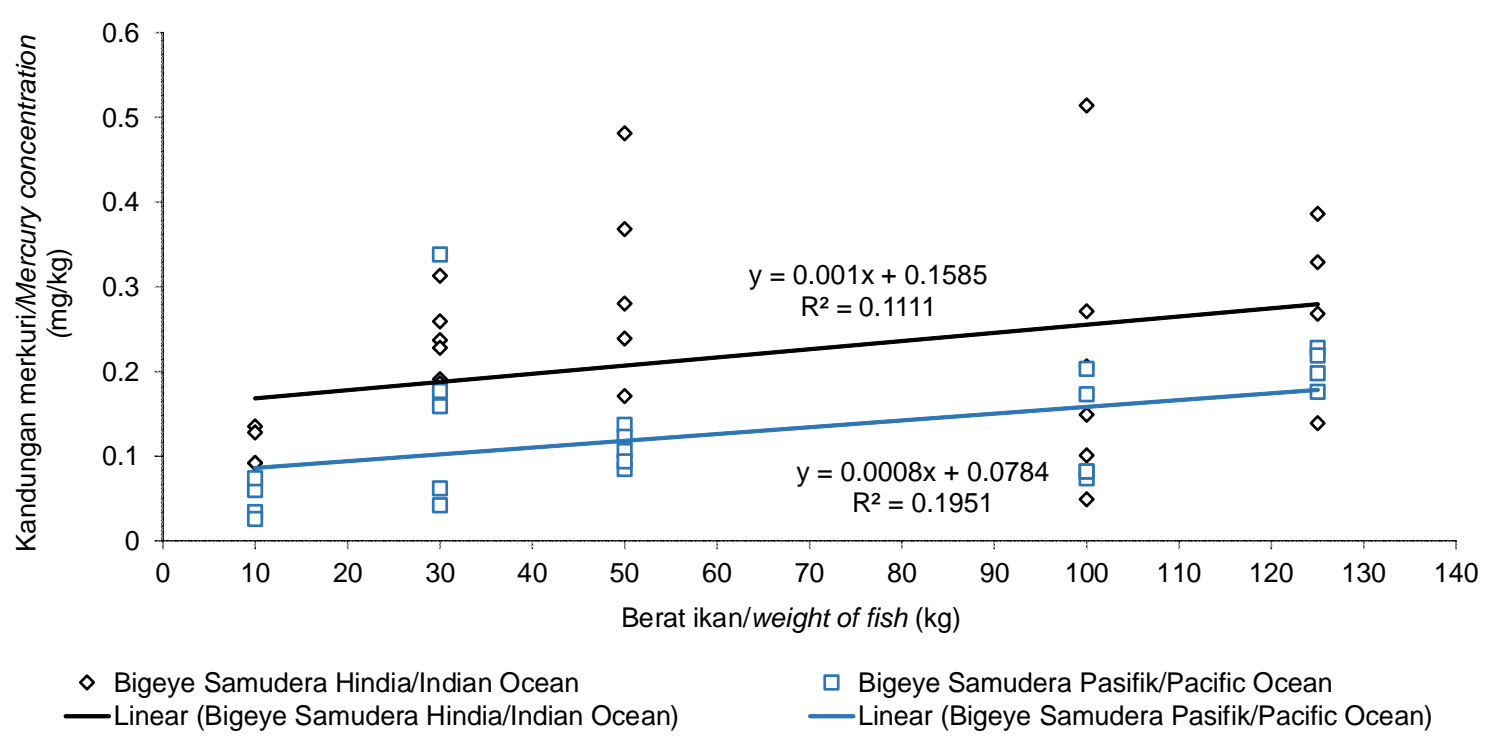

Sumber: BKIPM (2018b)

Gambar 5. Korelasi antara konsentrasi merkuri dengan berat bigeye tuna hasil tangkapan di Samudera Hindia dan Samudera Pasifik

Figure 5. Correlation between mercury concentration and weight of bigeye tuna caught from the Indian and the Pacific Oceans

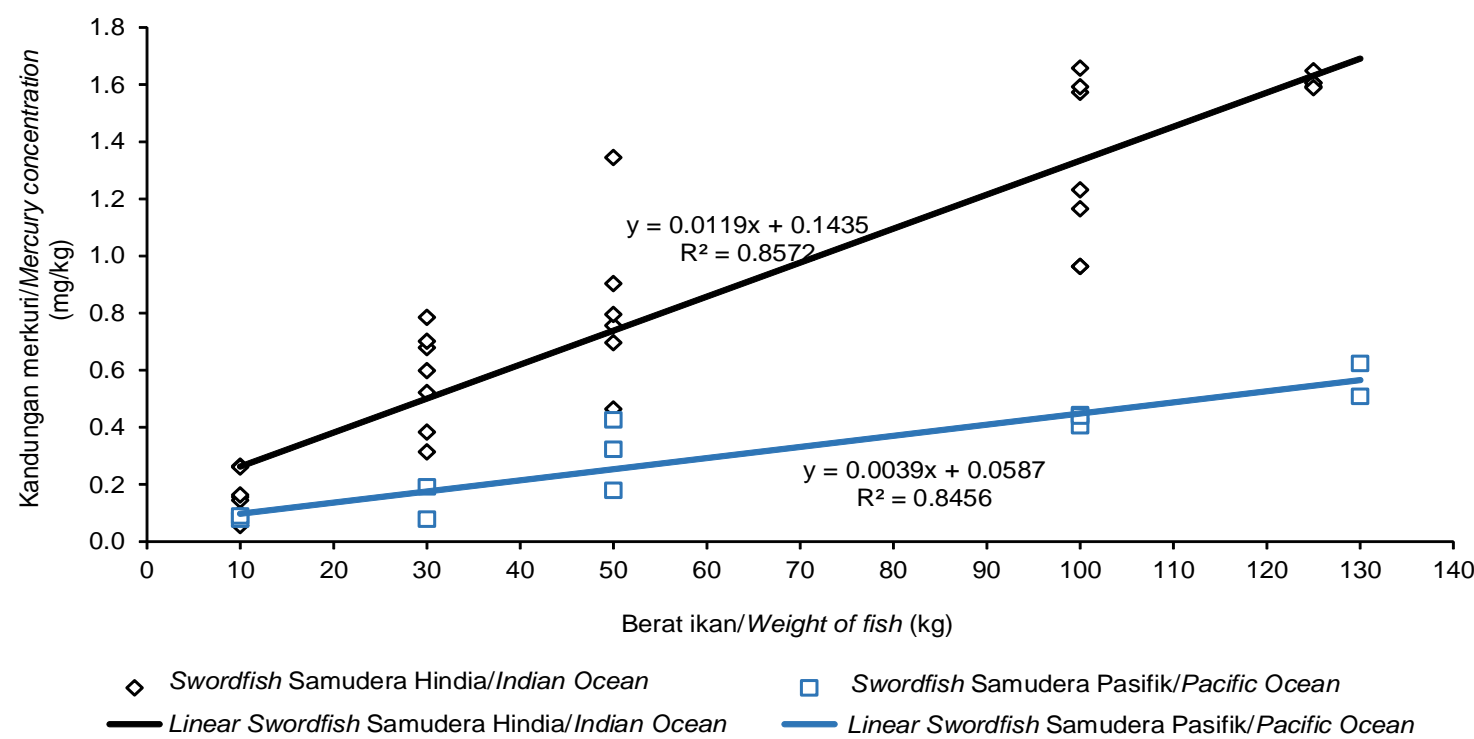

Sumber: BKIPM (2018b)

Gambar 6. Korelasi antara konsentrasi merkuri dengan berat swordfish hasil tangkapan di Samudera Hindia dan Samudera Pasifik

Figure 6. Correlation between mercury concentration and weight of swordfish caught from the Indian and the Pacific Oceans 
Hasil analisis regresi linier menunjukkan bahwa secara umum, berat ikan tuna dan tuna-like cenderung tidak berkorelasi terhadap peningkatan rata-rata kandungan merkuri, namun pada bigeye tuna terdapat perbedaan konsentrasi merkuri yang signifikan antara kelompok berat $1-10 \mathrm{~kg} /$ ekor dengan ukuran yang lebih besar, terutama yang berukuran di atas $100 \mathrm{~kg} /$ ekor. Sedangkan swordfish pada kelompok berat yang sama, rata-rata kandungan merkuri berkorelasi kuat dengan berat ikan. Ion metil merkuri mudah dimakan oleh biota perairan dalam sistem rantai makanan karena sifatnya yang mudah larut dalam air (Palar, 2004), yang selanjutnya dimakan oleh organisme air tingkat trofik terendah, hingga berlanjut pada biota tingkat trofik tertinggi (Klaassen, Doull, \& Amdur, 1986). Perbedaan trend rata-rata kandungan merkuri pada tuna dan tuna-like, diduga berkaitan juga dengan pola mangsa dalam rantai makanan. Connel dan Miller (1995) menyatakan bahwa peningkatan kandungan merkuri pada ikan tuna dan tuna-like bisa terjadi karena proses bioakumulasi dan biomagnifikasi secara terus menerus melalui rantai makanan. Swordfish merupakan jenis predator teratas (apex predator), yang memiliki tingkat kerakusan tinggi dibanding jenis ikan lain (Olvera, Garcia, Valdez, \& Sanchez, 2018; Sierra et al., 2016), sehingga dimungkinkan menjadi penampung terakhir (end reservoir) terhadap akumulasi "trace element" pada rantai makanan (Mansour \& Sidky, 2002).

Korelasi antara kandungan merkuri dan berat ikan pada tuna dan swordfish yang berbeda, diduga berkaitan dengan kemampuan ikan untuk mengeluarkan merkuri yang masuk ke dalam tubuhnya. Hal ini sejalan dengan pendapat Koeman (1987) bahwa secara alami, ikan memiliki kemampuan untuk mengeluarkan bahan toksik dari tubuhnya (homeostatis) melalui sekresi cairan pencernaan dalam jumlah yang relatif lebih tinggi dibanding biasanya dan proses detoksifikasi untuk mengurangi kadar racun dalam tubuhnya melalui proses biokimia atau proses lainnya. Riani (2012) menyatakan bahwa, apabila jumlah merkuri melebihi ambang batas, maka hati tidak mampu mendetoksifikasi sehingga merkuri beredar ke seluruh tubuh dan sebagian berikatan dengan gugus sulfidril yang bersifat irreversible. Tingkat kerakusan swordfish yang lebih tinggi dibandingkan dengan tuna (Nootmorn et al., 2007; Portier et al., 2007), diduga juga ikut berpengaruh terhadap menurunnya kemampuan untuk menetralisir merkuri yang masuk ke dalam tubuhnya dibandingkan dengan tuna.

\section{Lokasi Potensial Kontaminan Merkuri pada Ikan Tuna dan Tuna-like}

Pengujian hipotesis menggunakan uji beda (independent sample t-test) dilakukan untuk mengetahui perbedaan rata-rata antara ikan hasil tangkapan dari Samudera Hindia dan Samudera Pasifik. Konsentrasi merkuri pada ikan tuna dan tunalike hasil tangkapan dari Samudera Hindia lebih tinggi dibandingkan dengan Samudera Pasifik. Konsentrasi merkuri tertinggi untuk yellowfin dan bigeye tuna dari Samudera Pasifik masing-masing sebesar $0,20 \mathrm{mg} /$ $\mathrm{kg}$ dan $0,21 \mathrm{mg} / \mathrm{kg}$ sedangkan hasil tangkapan dari Samudera Hindia masing-masing sebesar $0,33 \mathrm{mg} /$ $\mathrm{kg}$ dan $0,39 \mathrm{mg} / \mathrm{kg}$. Swordfish hasil tangkapan dari Samudera Pasifik memiliki konsentrasi tertinggi ratarata sebesar $0,57 \mathrm{mg} / \mathrm{kg}$, sedangkan tangkapan dari Samudera Hindia melewati $1,0 \mathrm{mg} / \mathrm{kg}$, yaitu sebesar $1,61 \mathrm{mg} / \mathrm{kg}$.

Rata-rata kandungan merkuri pada yellowfin tuna, bigeye tuna dan swordfish hasil tangkapan di Samudera Hindia dengan hasil tangkapan di Samudera Pasifik berbeda nyata. Jinadasa et al. (2013), menyatakan bahwa kandungan merkuri dalam spesies tertentu sangat bervariasi, tergantung pada ukuran ikan, posisinya dalam rantai makanan, dan area penangkapan. Hal ini diperlihatkan dari kandungan merkuri swordfish dari Sri Lanka yang lebih tinggi dibandingkan swordfish yang berasal dari Samudera Atlantik dan Kepulauan Mozambik. Perbedaan yang nyata antara kandungan merkuri tuna dan tuna-like antara hasil tangkapan di perairan Samudera Hindia dan Samudera Pasifik, diduga berkaitan dengan penggunaan merkuri oleh industri, baik yang berasal dari limbah maupun buangan emisi yang berdampak pada pencemaran di masing-masing lingkungan perairan. Driscoll et al. (2013), menyatakan bahwa emisi global merkuri berkisar antara 6.500 hingga $8.200 \mathrm{mg}$ per tahun.

Asia merupakan wilayah regional terbesar pengguna merkuri di dunia, khususnya pada industri pertambangan emas skala kecil atau artisanal smallscale gold mining (ASGM). Hal ini sesuai dengan pernyataan dari United Nations Environment Programme (UNEP) bahwa penggunaan merkuri dunia terbesar pada industri ASGM berada di wilayah Asia dan Afrika, dengan jumlah sebesar 1.011 ton dibandingkan penggunaan total dunia sebesar 1.735 ton (UNEP, 2017). Limbah dari industri tersebut diduga bermuara ke Samudera Hindia dan menyebabkan perairan terkontaminasi merkuri. Di lain pihak, Samudera Pasifik cenderung tidak tercemar karena berada di antara negara-negara maju yang menerapkan aturan penggunaan merkuri yang sangat ketat. Negara di sekitar Samudera Pasifik menyumbang emisi merkuri bukan disebabkan pembuangan limbah oleh industri secara langsung ke lingkungan, tetapi karena pelepasan emisi merkuri dari proses produksi, yaitu pembakaran pada pertambangan batubara, industri semen dan produksi logam non-ferrous (UNEP, 2013). 


\section{KESIMPULAN}

Berdasarkan analisis data, dapat disimpulkan bahwa: 1) Kandungan merkuri sangat bervariasi antar jenis ikan, berat ikan dan asal perairan Samudera Hindia atau Samudera Pasifik. Rata-rata kandungan merkuri ikan tuna tidak melebihi $1,0 \mathrm{~m} / \mathrm{g} / \mathrm{kg}$ dan berat ikan cenderung tidak berkorelasi dengan kandungan merkuri, namun terdapat perbedaan yang signifikan antara konsentrasi merkuri pada bigeye tuna kelompok berat $1-10 \mathrm{~kg} / \mathrm{ekor}$ dengan ukuran yang lebih besar (>100 kg/ekor). Sedangkan pada swordfish, kandungan merkuri meningkat dengan penambahan berat ikan dan pada ukuran $>50 \mathrm{~kg}$ terdapat swordfish dengan kandungan $\mathrm{Hg}$ melebihi batas $1,0 \mathrm{mg} / \mathrm{kg}$. 2) Perairan Samudera Hindia cenderung lebih tercemar merkuri dibanding Samudera Pasifik, hal ini berkaitan dengan penggunaan dan pembuangan limbah merkuri dari industri di negara yang berada pada lintasan Samudera Hindia, sedangkan negara pada lintasan Samudera Pasifik cenderung menerapkan aturan penggunaan merkuri yang sangat ketat.

\section{DAFTAR PUSTAKA}

Alfian, Z. (2006). Merkuri antara manfaat dan efek penggunaannya bagi kesehatan manusia dan lingkungan. Pidato Pengukuhan Jabatan Guru Besar Tetap Universitas Sumatera Utara. 1 Mei 2006.

Badan Karantina Ikan Pengendalian Mutu dan Keamanan Hasil Perikanan (BKIPM)] . (2018a). Data Pusat Pengendalian Mutu. Jakarta: Kementerian Kelautan dan Perikanan. Tidak dipublikasikan.

Badan Karantina Ikan, Pengendalian Mutu dan Keamanan Hasil Perikanan (BKIPM). (2018b). Data pengujian merkuri di Unit Pengolahan Ikan dalam rangka penerbitan Health Certificate tahun 20122017. Jakarta: Kementerian Kelautan dan Perikanan. Tidak dipublikasikan.

Badan Standardisasi Nasional (BSN). (2006). Cara uji kimia-bagian 6: penentuan kadar logam berat merkuri $(\mathrm{Hg})$ pada produk perikanan. SNI 01-2354.62006. Jakarta.

Badan Standardisasi Nasional (BSN). (2009). Batas maksiumum cemaran logam berat dalam pangan. SNI 7387-2009. Jakarta.

Burger, J., \& Gochtel, M. (2004). Mercury in canned tuna: white versus light and temporal variation. $J$. Environmental Research, 96, 239-249. doi:10.1016/ j.envres.2003.12.001

Codex Alimentarius Commision (CAC). (2015). General standard for contaminants and toxins in food and feed (Codex stan 193-1995). Codex Alimentarius International Food Standards. FAO-WHO.

Chen, M. H., Chen, C. Y., Chang, S. K., \& Huang, S. W. (2007). Total and organic mercury concentrations in the white muscles of swordfish (Xiphias gladius) from the Indian and Atlantic oceans. Food Additives and Contaminants, 24(9), 969-975. https://doi.org/ $10.1080 / 12652030701305470$.
Connell, W., \& Miller, G. (1995). Kimia dan Ekotoksikologi Pencemaran (diterjemahkan oleh Yanti Koestoer dan Sahati). Jakarta: UI Press.

Darmono. (1995). Logam dalam Sistem Makhluk Hidup. Jakarta: UI Press.

Driscoll, C. T., Mason, R. P., Chan, H. M., Jacob, D. J., \& Pirrone, N. (2013). Mercury as a global pollutant: sources, pathways, and effects. Environmental Science and Technology, 47, 4967-4983. http:// dx.doi.org/10.1021/es305071v.

European Commission (EC). (2008). Commission Regulation (EC), No 629/2008 of 2nd of July 2008. Amending Regulation (EC No. 1881/2006: Setting maximum levels for certain contaminants in foodstuffs. Official Journal European Union, 173, 69.

European Commission (EC). (2017). RASFF-The rapid alert system for food and feed portal. Retrieved from https://webgate.ec.europa.eu/rasff-window/portal/ ? event=searchForm\&cleanSearch $=1$.

Galand, G., Rogers, A., \& Nickson, A. (2016). Netting billions: A global valuation of tuna. Washington DC: The Pew Charitable Trust Fund.

Ghaeni, M., Pour, N. A., \& Hosseini, M. (2015). Bioaccumulation of polychlorinated biphenyl (PCB), polycyclic aromatic hydrocarbon (PAH), mercury, methyl mercury and arsenic in blue crab Portunus segnis from Persian Gulf. Journal of Environmental Monitoring and Assesment, 187(5), 253-261. doi: 10.1007/s10661-015-4459-9.

Gobert, S., Pasqualini, V., Dijoux, J., Lejeune, J., Durieux, E. D. H., \& Marengo, M. (2017). Trace element concentrations in the apex predator swordfish (Xiphias gladius) from a Mediterranean fishery and risk assessment for consumers. Marine Pollution Bulletin, 120(1-2), 364-369. http://dx.doi.org/10.1016/ j.marpolbul.2017.05.029.

Jinadasa, B. K. K. K., Edirisinghe, E. M. R. K. B., \& Wickramasinghe, I. (2013). Total mercury content, weight and length relationship in swordfish (Xiphias gladius) in Sri Lanka. Food Additives \& Contaminants: Part B: Surveillance, 1-5. doi:10.1080/ 19393210.2013.807521.

Jinadasa, B. K. K. K., Jayasinghe, G. D. T. M., Edirisinghe, E. M. R. K. B., \& Wickramasinghe, I. (2015). Mercury concentration of muscle tissue and relationship with size of yellowfin tuna, Thunnus albacares, of the Indian Ocean. European Journal of Academic Essays, 2(4), 35-40.

Kantun, W., Mallawa, A. \& Rapi, N. L. (2014). Perbandingan struktur ukuran tuna madidihang (Thunnus alabacares) yang tertangkap pada rumpon laut dalam dan laut dangkal di Perairan Selat Makassar. Jurnal IPTEKS PSP, 1(2), 112-128.

Kementerian Kelautan dan Perikanan (KKP). (2017). Ekspor tuna cakalang tongkol Indonesia 6 tahun terakhir (2012-2017), kondisi dan harapan. Retrieved from https://kkp.go.id/djpdspkp/artikel/2746-eksportuna-cakalang-tongkol-indonesia-6-tahun-terakhir2012-2017-kondisi-dan-harapan. 
Klaassen, C. D., Doull, J. \& Amdur, M. O. (1986). Toxicology. The Basic Science of Poisons. (3th. Ed.). New York: Macmillan Publishing Company.

Koeman, J. H. (1987). Pengantar Umum Toksikologi. (diterjemahkan oleh Yudono). Yogyakarta: Gadjahmada University Press.

Kojadinovic, J., Potier, M., Corre, L. M., Cosson, R. P., \& Bustamante, P. (2006). Mercury content in commercial pelagic fish and its risk assessment in the Western Indian Ocean. Science of the Total Environment, 366(2-3), 688-700. doi:10.1016/ j.scititenv.2006.02.006.

Lamborg. C.H., Hammerschmidt, C.R., Bowman, K.L., Swarr, G.J., Munson, K.M., Ohnemus, D.C., Lam, P.J., Heimbürger, L.E., Rijkenberg, M.J., \& Saito, M.A. (2014). A global ocean inventory of anthropogenic mercury based on water column measurements. Nature. 512: 65-68. http://dx.doi.org/10.1038/ nature13563.

Llaurado, G. M., Garcia, P. M., Escribano, J., Monasterolo, C. R., Luque, V., Grote, V., Weber, M., Espínola, F. J, Kowalska, J. C, Verduci, E., Martin, F., Piqueras, M. J., Koletzko, B., Decsi, T., Campoy, C., \& Emmet, P. P. (2016). Fish consumption in mid-childhood and its relationship to neuropsychological outcomes measured in 7-9 year old children using a nutrimenthe neuropsychological battery. Journal of Clinical Nutrition, 35(6), 1301-1307. https://doi.org/ 10.1016/j.clnu.2016.02.008.

Llop, S., Ballester, F., Murcia, M., Forns, J., Tardon, A., Andiarena, A., Vioque, J., Ibarluzea, J., Somoano, A.F., Sunyer, J., Julvez, J., Rebagliato, M., \& Espinosa, M, J, L. (2017). Prenatal exposure to mercury and neuropsychological development in young children: the role of fish consumption. International Journal of Epidemiology, 46(3), 827-838. https://doi.org/ 10.1093/ije/dyw259.

Mansour, S. A., \& Sidky, M. M. (2002). Ecotoxicological studies. Heavy metals contaminating water and fish from Fayoum Governorate. Egypt. Food Chem, 78, 15 -22.http://dx.doi.org/10.1016/S0308 8146(01)00197-2.

Nicklisch, S. C. T., Bonito, L. T., Sandin, S., \& Hamdoun, A. (2017). Mercury levels of yellowfin tuna (Thunnus albacares) are associated with capture location. Journal of Environmental Pollution, 229, 87-93. http:/ /dx.doi.org/10.1016/j.envpol.2017.05.070.

Nootmorn, P., Sumontha, M., Keereerut, P., Jayasinghe, R. P. P., Jagannath, N., \& Sinha, M. K. (2007). Stomach content of the large pelagic fishes in the Bay of Bengal. IOTC-2008-WPEB-11, 1-13.

Olvera, A. T., Garcia, S. O., Valdez, A. T., \& Sanchez, O. E. (2018). Feeding habits of the wordfish (Xiphias gladius Linnaeus, 1758) in the subtropical northeast Pacific. Journal of Hydrobiologia, 822(1), 173-188. https://doi.org/10.1007/s10750-018-3680-2.

Palar, H. (2004). Pencemaran dan Toksikogi Logam Berat. Jakarta: Penerbit Rineka Cipta.
Portier, M., Marsac, F., Cherel. Y., Lucas, V., Sabatie, R., Maury, O., \& Menard, F. (2007). Forage fauna in the diet of three large pelagic fishes (lancet, swordfish and yellowfin tuna) in the western equatorial Indian Ocean. Fisheries Research, 83, 60-72. doi:10.1016/ j/fishres.2006.08.020.

Riani, E. (2012). Perubahan Iklim dan Kehidupan Akuatik (Dampak pada Bioakumulasi Bahan Berbahaya dan Beracun \& Reproduksi). Bogor: IPB Press.

Riani, E., Sudarso, Y., \& Cordova, M. R. (2014). Heavy metals effect on unviable larvae of Dicrotendipes simpsoni (Diptera: Chironomidae), a case study from Saguling Dam, Indonesia. International Journal of the Bioflux Society, 7(2), 76-84.

Riani, E. (2015). The effect of heavy metals on tissue damage in different organs of goldfish cultivated in floating fish net in Cirata Reservoir, Indonesia. PARIPEX - Indian Journal of Research, 4(2), 54-58.

Sierra, D. M., Tiznado, M. E. B., Farias, F. M., Rojas, Y. E. T., Inzuna, J. R. R., \& Osuna, F. P. (2016). Trace metals in target tissues and stomatch contents of the top predator sailfish Istiophorus platypterus from the Eastern Pacific: concentrations and contrasting behavior of biomagnification. Journal of Environmental Science Pollution Research, 23(23), 23791-23803. doi:10.1007/s11356-016-7551-y.

Storelli, M. M., Giacominelli-Stuffler, R., Storelli, A., Marcotrigiano, G. O. (2005). Accumulation of mercury, cadmium, lead and arsenic in swordfish and bluefin tuna from the Mediterranean Sea: a comparative study. Marine Pollution Bulletin, 50, 1004-1007. http:/ /dx.doi.org/10.1016/j.marpolbul.2005.06.041.

Sunderland, E. M, \& Mason, R. (2007). Human impact on ocean mercury concentration. Global Biogeochemical Cycles, 21, 1-15. doi:10.1029/ 2006 GB002876.

United Nations Environment Programme (UNEP). (2013). Global Mercury Assessment 2013: Sources, emissions, releases and environmental transport. Geneva, Switzerland: United Nations Environment Programme Chemicals and Health Branch.

United Nations Environment Programme (UNEP). (2017). Global mercury supply, trade and demand. Geneva, Switzerland: United Nations Environment Programme Chemicals and Health Branch.

Yi, Y., Tang, C., Yi, T., Yang, Z., \& Zhang, S. (2017). Health risk assessment of heavy metals in fish and accumulation patterns in food web in the upper Yangtze River, China. Journal of Ecotoxicology and Environmental Safety, 145, 295-302. https://doi.org/ 10.1016/j.ecoenv.2017.07.022.

Yilmaz, W. (2009). The comparison of heavy metal concentrations ( $\mathrm{Cd}, \mathrm{Cu}, \mathrm{Mn}, \mathrm{Pb}$, and $\mathrm{Zn}$ ) in tissues of three economically important fish (Anguilla anguilla, Mugil cephalus and Oreochromis niloticus) Inhabiting Köycegiz Lake-Mugla, Turkey. Turkish Journal of Science and Technology, 4(1), 7-15. 
JPB Kelautan dan Perikanan Vol. 14 No. 1 Tahun 2019: 35-44 